\title{
1 Relevance of screening for Chagas and viral hepatitis in Bolivian \\ 2 migrants \\ 3
}

4 Irene Losada Galván*1, Giuseppe Gariup ${ }^{2}$, Aina Casellas ${ }^{1}$, Carme Subirà ${ }^{1}$, Alex Almuedo-Riera

$5 \quad$ 1,3, Daniel Camprubí ${ }^{1}$, Natalia Rodríguez-Valero ${ }^{1}$, Joaquim Gascón ${ }^{1}$, Jose Muñoz ${ }^{1}$, María Jesús

6 Pinazo*1

7 (1) ISGlobal, Hospital Clínic - Universitat de Barcelona, Barcelona, Spain. (2) Internal Medicine,

8 Hospital Clinic, Barcelona. (3) Internal Medicine, Hospital General de Granollers, Barcelona

9

$10 *$ Both authors as corresponding authors

11 irenelosada@gmail.com \& mariajesus.pinazo@isglobal.org

\section{Abstract}

13 Objectives: given the scarcity of data regarding prevalence of various infectious diseases in

14 Latin-American countries, our study aims to assess the burden of T.cruzi, S.stercoralis, HIV and

15 viral hepatitis in Latin-American migrants, with a focus on Bolivian migrants.

16 Methods: we performed a retrospective observational study of 565 screening evaluations on

17 adults ( $\geq 18$ years) carried out at our referral International Healthcare service in Barcelona. We reviewed structured clinical records and microbiological results of patients attended between February 2012 and April 2015.

20 Results: the median 35 years old and $74 \%$ were women. Bolivian origin accounted for $87 \%$ of

21 the screened population. We found a $48 \%$ prevalence of T.cruzi, $16 \%$ of S.stercoralis, $0.2 \%$ of 22 HIV, $92 \%$ of HAV, $0.2 \%$ HBV and $0.2 \%$ HCV. 
23 Conclusions: these results support the relevance of the screening of T. cruzi and S. stercoralis

24 in Bolivian migrants, but challenge the pertinence of systematic screening of $\mathrm{HBV}$ in this

25 population.

26

\section{Author summary}

In response to the challenge of detecting diseases not previously present in host countries, screening programs have been implemented for migrants based on the probability of having certain diseases depending on their country of origin and / or migratory route. This increased risk is very clearly established in some cases such as Trypanosoma cruzi infection (the cause of Chagas disease) in people from Latin America; especially from Bolivia. In recent years screening recommendations for Strongyloides stercoralis in this population was proven necessary. Current recommendations regarding systematic screening for hepatitis B establish the relevance of screening based on the probability of the disease in the $2 \%$ population of origin. Since there are no reliable and up to date data regarding prevalence of hepatitis B virus in Bolivia, we aimed to analyze data available for migrants from Bolivia in Spain.

Our results support the importance of screening for T. cruzi and S.stercoralis in patients from Bolivia. However, our data show a much lower prevalence of this hepatitis B virus $(0.2 \%)$ than the $2 \%$ threshold that would justify systematic screening, so we question the relevance of screening for hepatitis B virus in this population in the absence of other risk factors.

\section{Introduction}

The increase in global migratory movements in recent decades implies new challenges for health professionals and policy makers, especially regarding the need to diagnose and treat previously non-endemic pathologies in the host countries. One of the diseases that best illustrates this challenge is Chagas disease, caused by chronic infection by Trypanosoma cruzi 
parasite.

It is estimated that 6-7 million people worldwide are infected with T.cruzi, mainly in Latin America (LA), where it causes more than 10000 deaths per year(1). The first reports of Chagas disease in Europe were published in the early 1980s, with a marked increase around 2000, along with the rising flow of migrants from LA to Europe(2-4). From 2007 onwards, a number of initiatives both at national and international levels have been implemented in order to increase awareness and provide better care to potentially affected populations (5). These aim for better control vertical transmission (congenital, from mother to fetus)(6) and transmission by infected blood and organ donors $(7,8)$. Such initiatives include screening programs, which are often the first contact of the migrant with the health system in host countries. Thus, they represent an opportunity for a thorough medical examination and complementary tests. The indication of performing these diagnostic tests derives from the estimated prevalence for each risk group, using the country of origin in the absence of other known risk factors $(9,10)$.

The relevance of conducting Chagas disease screening in Latin American migrants is based on epidemiological data from the countries of origin as well as data from recipient countries: WHO estimates a global prevalence of $1 \%$ in LA countries(11), with great variations within the different countries in the region (highest prevalence in Bolivia 6.1\% and Paraguay 2.1\%). Data from non-endemic areas shows similar results: a meta-analysis(12) on prevalence of Chagas disease in Europe estimated a prevalence of $4.2 \%$, also with important variations according to country of origin, with the highest prevalence among Bolivian immigrants (18\%). In addition, there are studies in favor of the cost-effectiveness of screening for Chagas disease in this context $(13,14)$.

Another well-established indication for screening would be Strongyloides stercoralis, with an estimated prevalence of 370 million worldwide (15) and regional LA country-specific prevalence ranging from 1 to $73 \%(16,17)$. S. stercoralis chronic infection is usually 
asymptomatic, but it can develop into a severe and highly lethal disease in the context of immunosuppression(18). The association of T.cruzi infection with a two-fold increase in the odds of strongyloidiasis (19) support this combined strategy of screening (T.cruzi - S.stercoralis) in LA migrants.

WHO estimates that in 2015, 257 million persons were living with chronic Hepatitis B Virus (HBV) infection in the world, 68\% in African and Western Pacific regions(20). Chronic HBV infection is usually asymptomatic, but $20-30 \%$ of patients with chronic VHB infection will develop complications (including liver cirrhosis and hepatocellular carcinoma). Testing for chronic HBV infection meets established public health screening criteria(21). In the absence of specific risk factors such as blood transfusion recipients before 1991, injectable drug users, men who have sex with men; a geographic-based screening is performed based on the HBV prevalence of the countries of origin. Before 2008 the HBV prevalence threshold was established at $8 \%$ (high endemicity countries), that was then lowered to a $2 \%$ prevalence (medium endemicity) in the updated recommendations of the $\mathrm{CDC}(22)$. Ever since there is a broad consensus on the relevance and cost-effectiveness of screening for hepatitis B in people from countries with prevalence greater than $2 \%(23)$. However this figure is currently under discussion: a study performed in the United States argued that it would be cost-effective screening in populations with prevalence as low as 0,3\%(24). Both European(25-27) and American (28-30) guidelines recommend screening in migrants coming from countries with a HBV prevalence of $2 \%$ or higher. However, the discussion of the screening threshold becomes futile when epidemiological studies on which the recommendations are based by each country are scarce, not updated and often conflicting. The WHO estimates an overall prevalence in the region of the Americas between 0.4 and 1.6\%(31), with 7-12 million Latin Americans carrying HBV chronic infection(32). In the case of Bolivia, there is conflicting evidence with regard to its HVB infection prevalence. A meta-analysis(33) showed a prevalence of between 0.1 and $6 \%$, but its baseline data oscillate between 1987 and 2008, with a total sample of 1930 patients. 
97 Another systematic review (34) estimates a prevalence of HBV in Bolivia of $0.44 \%$ based on 4

98 studies (1357 patients).

99 The scenario of chronic infection with hepatitis $\mathrm{C}$ virus (HCV) is very different. The prevalence

100 of this disease is higher in Spain (1.7\%) compared to the prevalence in Latin American

101 countries (1.1\%-1.3\%, Bolivia 0.9\%) (27,35). Therefore, given the low prevalence in LA

102 countries, screening indication would be given in any case by risk factors different from the

103 country of origin. However, some authors argue that HCV screening should be performed

104 anytime HBV screening is indicated for another reason.

105 According to 2016 ECDC epidemiological assessment(36), estimates of total number of

106 migrants infected with HCV or HBV might be an overestimation, since prevalence if often lower

107 in migrants compared to the prevalence of the country of origin.

Data on serologic prevalence of viral hepatitis in LA migrants in Spain is scarce and often

Centre in Madrid (37) found 1.6\% chronic HBV infection in LA migrants. These results are

similar to a $1.6 \%$ and $1.2 \%$ chronic HBV infection from a referral center (38) and a primary care study (39) both in Barcelona; as opposed to a $0.6 \%$ overall prevalence found on another study in the UK(40).

Considering the scarcity of data of the previously stated entities in LA migrants, our study aims to assess the burden of these infectious diseases in Latin-American migrants attending a referral International Healthcare service in Barcelona, with a focus on Bolivian migrants. We intend to contribute our data to those of other migrant cohorts in high income countries, given that they are a useful source of information on the prevalence of various infectious diseases when reliable data from the countries of origin are not available. We evaluate the number of chronic infections in the target population in comparison with that of their countries of origin in order to assess the pertinence of the systematic screening in this population. 
123 This retrospective observational study was performed at the International Health department

124 of the Hospital Clinic of Barcelona. We reviewed medical records from all patients at risk of

125 T.cruzi infection attending our unit between February 2012 and April 2015.

In our clinic we perform screening evaluations on adults (age 18 or older) who come from Latin

American Countries. They come to the clinic either spontaneously, counseled by friends or guidelines.

Epidemiological data include age, sex, country of origin, year of arrival in Spain, risks factors for transfusions, mother affected with Chagas disease) and risk factors for hepatitis (blood transfusions, unprotected sexual relationships). The usual screening workup includes a blood cell count, general biochemistry, serologies for T. cruzi, S. stercoralis, HIV, HBV and HCV. HAV was tested according to physician preference. Stool samples are collected for parasitological examination.

Screening of Chagas was performed with a chemiluminescent microparticle immunoassay

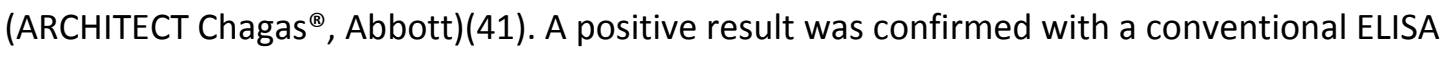
with recombinant antigens (CHAGAS ELISA IgG+IgM, Vircell)(42) as per WHO recommendations

142 for diagnosis(43). S. stercoralis infection was diagnosed by direct visualization of ova in stool or 143 a positive one-step sandwich-format immunoassay for the qualitative detection of IgG-class 144 antibodies to Strongyloides stercoralis antigen (Strongyloides ELISA, SciMedx)(44). Detection of hepatitis B virus surface antigen (HBsAgll, Advia Centaur) (45), antibody against hepatitis B virus core (HBc Total, Advia Centaur) (46) and surface antigen (antiHBs 2, Advia Centaur)(47) 
147 were used to assess HBV status. Active infection was considered if HBsAg was positive;

148 vaccination if $\mathrm{HBsAg}$ was negative, $\mathrm{HBsAb}$ positive and $\mathrm{HBcAb}$ negative, and cured infection if

$149 \mathrm{HBsAg}$ is negative and $\mathrm{HBsAb}$ and $\mathrm{HBcAb}$ positive. Accurate classification was not always

150 possible since not all the individuals in the cohort had a complete serology. Antibodies against hepatitis A (HAV Total, Advia Centaur)(48) and C (HCV, Advia Centaur)(49) viruses were used to detect passed HAV infection and to screen for chronic HCV infection. Screening of HIV was made by a chemiluminometric immunoassay of antigen binding microparticles that is used to detect antibodies against human immunodeficiency virus type 1 , including subtype 0 , and / or type 2 (HIV 1 / O / 2 Enhanced Assay, Avia Centaur)(50).

Data were presented as frequencies and median (interquartile range, IQR) for discrete and continuous variables, respectively. Proportions were compared using Chi-squared test or Fisher's exact test if the application conditions of the former where not met. Medians were compared between groups using Wilcoxon Rank Sum test. Significance was set at 0.05 . The analysis was carried out using Stata 15 (StataCorp. 2017)(51). anonymized.

Over the study period, 565 individuals were screened for T. cruzi and other infectious diseases. The median (IQR) age was 35 (29 - 42) years old and $74 \%$ were women. Median (IQR) time elapsed from their arrival to the country and this screening was eight (7-10) years. Demographic characteristics and presence of risk factors for $T$. cruzi infection of the study population compared by $T$. cruzi results are shown in Table 1. Four hundred and ninety-five 
bioRxiv preprint doi: https://doi.org/10.1101/775890; this version posted September 19,2019 . The copyright holder for this preprint (which was not certified by peer review) is the author/funder, who has granted bioRxiv a license to display the preprint in perpetuity. It is made available under aCC-BY 4.0 International license.

171 remaining 71 individuals came from other Latin American countries, with Argentina as the next

172 most numerous country of origin $(21,4 \%)$.

173 Table 1. Demographic characteristics and T. cruzi risk factors

\begin{tabular}{|c|c|c|c|c|c|}
\hline \multirow{2}{*}{\multicolumn{2}{|c|}{ Variable }} & \multicolumn{2}{|c|}{ T.cruzi serology } & \multirow[b]{2}{*}{ Total } & \multirow[b]{2}{*}{ p-value } \\
\hline & & Negative & Positive & & \\
\hline \multicolumn{6}{|c|}{ Demographic characteristics } \\
\hline \multicolumn{2}{|c|}{ Gender (female) ${ }^{1}$} & $\begin{array}{r}193 / 292 \\
(66.1 \%)\end{array}$ & $\begin{array}{r}203 / 273 \\
(74.4 \%)\end{array}$ & $\begin{array}{r}396 / 565 \\
(70.1 \%)\end{array}$ & $0.0321^{2}$ \\
\hline \multicolumn{2}{|l|}{ Age $^{3}$} & $\begin{array}{r}33.5(27-41) \\
{[292]}\end{array}$ & $\begin{array}{r}37(32-44) \\
{[273]}\end{array}$ & $\begin{array}{r}35(29-42) \\
{[565]}\end{array}$ & $\begin{array}{c}< \\
0.0001^{4}\end{array}$ \\
\hline \multirow[t]{4}{*}{ Age ${ }^{1}$} & $0-25$ & $56(19.2 \%)$ & $11(4.0 \%)$ & $67(11.9 \%)$ & \multirow{4}{*}{$0.0001^{2}$} \\
\hline & $26-40$ & $162(55.5 \%)$ & $156(57.1 \%)$ & $318(56.3 \%)$ & \\
\hline & $>40$ & $74(25.3 \%)$ & $106(38.8 \%)$ & $180(31.9 \%)$ & \\
\hline & Total & $292(100.0 \%)$ & $273(100.0 \%)$ & $565(100.0 \%)$ & \\
\hline \multicolumn{2}{|c|}{ Preconsultation time (years) ${ }^{3}$} & $8(6-10)[292]$ & $8(7-10)[273]$ & $8(7-10)[565]$ & $0.3832^{4}$ \\
\hline \multicolumn{6}{|c|}{ Risk Factors for Chagas disease } \\
\hline \multicolumn{2}{|c|}{ Lived in rural areas ${ }^{1}$} & $\begin{array}{r}210 / 292 \\
(71.9 \%)\end{array}$ & $\begin{array}{r}245 / 273 \\
(89.7 \%)\end{array}$ & $\begin{array}{r}455 / 565 \\
(80.5 \%)\end{array}$ & $\begin{array}{c}< \\
0.0001^{2}\end{array}$ \\
\hline \multicolumn{2}{|c|}{ Adobe housing ${ }^{1}$} & $\begin{array}{r}212 / 290 \\
(73.1 \%)\end{array}$ & $\begin{array}{r}244 / 273 \\
(89.4 \%)\end{array}$ & $\begin{array}{r}456 / 563 \\
(81.0 \%)\end{array}$ & $\begin{array}{c}< \\
0.0001^{2}\end{array}$ \\
\hline \multicolumn{2}{|c|}{ Blood products recipients ${ }^{1}$} & $11 / 290(3.8 \%)$ & $19 / 270(7.0 \%)$ & $30 / 560(5.4 \%)$ & $0.0885^{2}$ \\
\hline \multicolumn{2}{|c|}{ Blood donors ${ }^{1}$} & $8 / 292(2.7 \%)$ & $3 / 273(1.1 \%)$ & $11 / 565(1.9 \%)$ & $0.1584^{2}$ \\
\hline
\end{tabular}




\begin{tabular}{|l|r|r|r|r|}
\hline Screening son/daughter of positive & $48 / 280$ & $32 / 270$ & $80 / 550$ & $0.0785^{2}$ \\
mother $^{1}$ & $(17.1 \%)$ & $(11.9 \%)$ & $(14.5 \%)$ \\
& & & \\
\hline
\end{tabular}

\section{5: Fisher's exact test}

177 Chagas disease. T. cruzi was positive in 273 participants (48\%) of the screened individuals.

Among them, there was a greater presence of known risk factors for $T$. cruzi infection as

but without significative difference.

We also compared T.cruzi positivity in relation to other infectious diseases, with results shown

Table 2. Hepatitis B virus screening by $T$. cruzi results

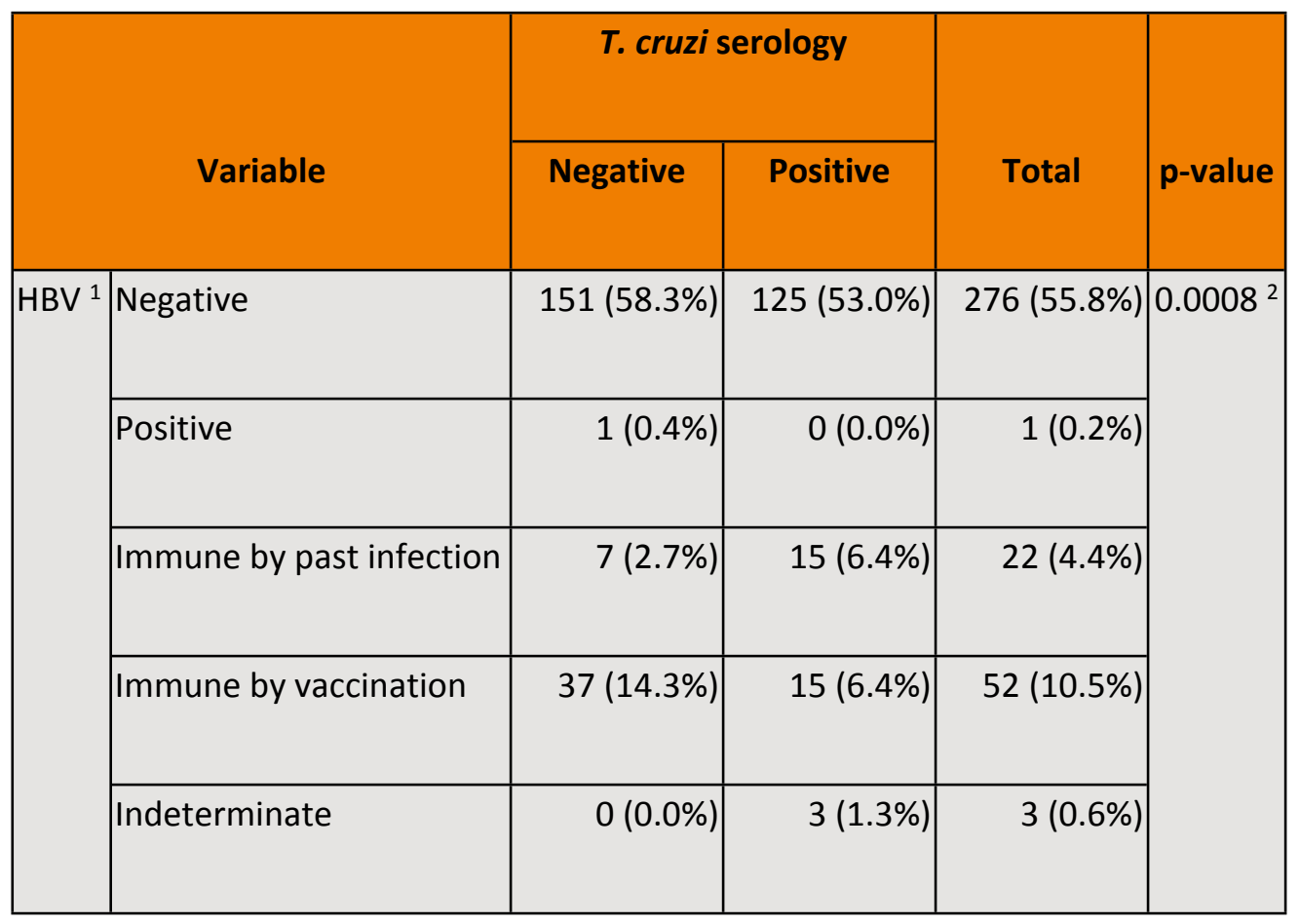




\begin{tabular}{|l|l|r|r|r|}
\hline Incomplete & $63(24.3 \%)$ & $78(33.1 \%)$ & $141(28.5 \%)$ \\
\cline { 2 - 5 } & Total & $259(100.0 \%)$ & $236(100.0 \%)$ & $495(100.0 \%)$ \\
\end{tabular}

HBV: hepatitis B virus

Negative: HBsAg-, HBsAb-, HBcAb-; Positive: HBsAg+; Immune by past infection: HBsAg-,

$\mathrm{HBsAb+}+\mathrm{HBcAb+}$; Immune by vaccination: HBsAg-, HBsAb+, HBcAb-; Indeterminate: HBsAg-,

HBsAb-, HBcAb+

Table 3. Other infectious diseases by T. cruzi results

\begin{tabular}{|c|c|c|c|c|c|}
\hline \multirow{2}{*}{\multicolumn{2}{|c|}{ Variable }} & \multicolumn{2}{|c|}{ T. cruzi serology } & \multirow{3}{*}{ Total } & \multirow{3}{*}{$p$-value } \\
\hline & & Negative & Positive & & \\
\hline \multicolumn{4}{|c|}{ Screening for other infectious diseases } & & \\
\hline \multirow[t]{3}{*}{ HIV } & Negative & $270(99.6 \%)$ & $253(100.0 \%)$ & $523(99.8 \%)$ & \multirow[t]{3}{*}{$1.0000^{3}$} \\
\hline & Positive & $1(0.4 \%)$ & $0(0.0 \%)$ & $1(0.2 \%)$ & \\
\hline & Total & $271(100.0 \%)$ & $253(100.0 \%)$ & $524(100.0 \%)$ & \\
\hline \multirow[t]{3}{*}{ HAV IgG ${ }^{1}$} & Negative & $15(11.5 \%)$ & $5(3.9 \%)$ & $20(7.8 \%)$ & \multirow[t]{3}{*}{$0.0229^{2}$} \\
\hline & Positive & $115(88.5 \%)$ & $122(96.1 \%)$ & $237(92.2 \%)$ & \\
\hline & Total & $130(100.0 \%)$ & $127(100.0 \%)$ & $257(100.0 \%)$ & \\
\hline $\mathrm{HCV}^{1}$ & Negative & $234(100.0 \%)$ & $223(99.6 \%)$ & $457(99.8 \%)$ & $0.4891^{3}$ \\
\hline
\end{tabular}




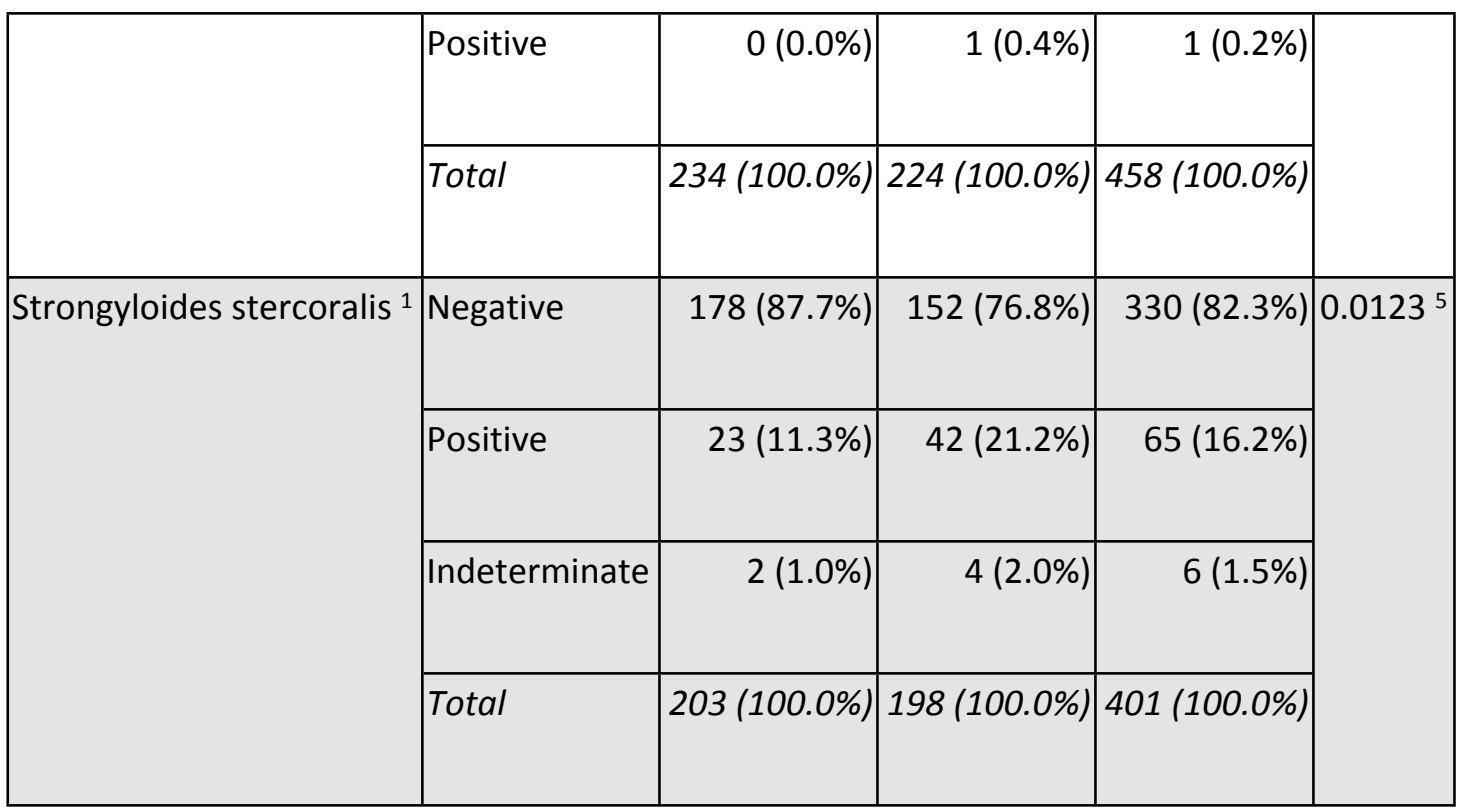

HIV: Human immunodeficiency virus; HAV: hepatitis A virus; HBV: hepatitis B virus; HCV:

1: $\mathrm{n}$ (Column percentage); 2: Chi-squared test; 3: Fisher's exact test

HIV. Serologic test for HIV was performed in $93 \%$ of the study population, with one positive result on a man who had sex with men, without other risk factors.

Hepatitis A virus. A serologic test for HAV was performed in $45 \%$ of the study population. A positive HAV was significantly more frequent among individuals who were also positive for T.cruzi, with an overall prevalence of $92 \%$. (Table 3)

Hepatitis B virus. A serologic test for HBV was performed in $88 \%$ (495) of the study population. 
210 several accidental punctures when he practiced dentistry in Bolivia.

211 The remaining 93\% had a negative serology for HBV or were immune by vaccination. The

212 prevalence of chronic/past infection was significantly higher among individuals who were also

213 positive for T. cruzi. Table 4 shows demographic characteristics and microbiological results of

214 Bolivian patients by HBV.

Table 4. Results from Bolivian migrants with respect to HBV results

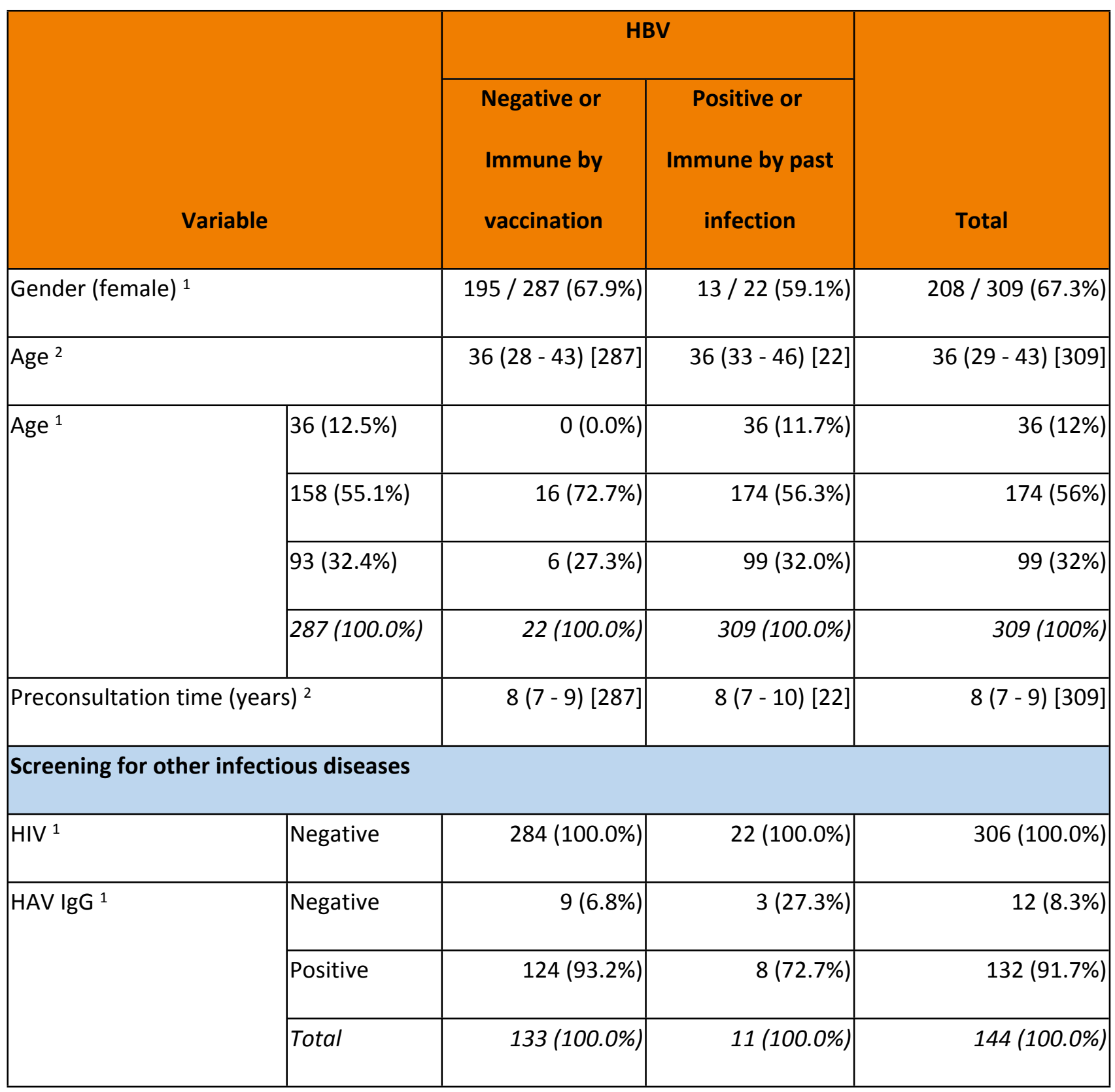




\begin{tabular}{|l|l|r|r|r|}
\hline HCV 1 & Negative & $257(99.6 \%)$ & $20(100.0 \%)$ & $277(99.6 \%)$ \\
\cline { 2 - 5 } & Positive & $1(0.4 \%)$ & $0(0.0 \%)$ & $1(0.4 \%)$ \\
\cline { 2 - 5 } & Total & $258(100.0 \%)$ & $20(100.0 \%)$ & $278(100.0 \%)$ \\
\hline \multirow{3}{*}{ Strongyloides stercoralis } & Negative & $146(50.9 \%)$ & $11(50.0 \%)$ & $157(50.8 \%)$ \\
\cline { 2 - 5 } & Positive & $30(10.5 \%)$ & $5(22.7 \%)$ & $35(11.3 \%)$ \\
\cline { 2 - 5 } & Indeterminate & $5(1.7 \%)$ & $0(0.0 \%)$ & $5(1.6 \%)$ \\
\cline { 2 - 5 } & Missing & $106(36.9 \%)$ & $6(27.3 \%)$ & $112(36.2 \%)$ \\
\cline { 2 - 5 } & Total & $287(100.0 \%)$ & $22(100.0 \%)$ & $309(100.0 \%)$ \\
\hline
\end{tabular}

HIV: Human immunodeficiency virus; HAV: hepatitis A virus; HCV: hepatitis C virus.

1: n (Column percentage); 2: Median (IQR) [n]

Hepatitis C virus. A serologic test for HCV was performed in $81 \%$ of the study population.

There was one positive result from a patient who was also positive for T. cruzi, but negative for

HBV and HIV. This patient was initially screened for HCV in 2014 with a negative result. During

follow-up, an elevation of transaminases advised a new a serological study, which was positive and was successfully treated with Sofosbuvir/Ledipasvir in 2017 (viral load undetectable since then).

Strongyloides stercoralis. A serologic test and/or stool sample for parasite examination was 
232 Strongyloides stercoralis infection was significantly higher in patients who were also positive

233 for T. cruzi (Table 3).

The aim of this study was to describe the prevalence of different infectious diseases in Bolivian and other Latin-American migrants attending a referral International Health service in order to establish more accurate screening protocols according to international recommendations. First we should acknowledge that the vast majority of the screened individuals were from Bolivia, and coming from several areas with a high migratory tradition (52). This limits the generalization of the results to the Latin American community as a whole, but provides with a robust source of information about the Bolivian community in our context. Hence, most of our analysis will apply only to Bolivian migrants.

Another relevant finding is a prevalence for $T$. cruzi infection as high as $48 \%$ of the screened population. This is probably due to various reasons. First, the majority of the screened population was from highly endemic areas in Bolivia (with an expected prevalence of $18 \%)(12)$. Secondly, some patients already know about their diagnosis before coming to our clinic. advice of inviting their relatives to the screening program. Thus, this unusually high prevalence of Chagas disease might be influenced by community and family clusters that share risk factors for the disease. These risk factors include having lived in a house made of adobe and having lived in rural areas, which are both significant risk factors for $T$. cruzi in this study population. Interestingly, in our cohort, having received blood products was not statistically associated with a higher risk of $T$. cruzi infection. This might be due to the relative small number of patients who did receive some blood product in their countries of origin, but it might also be 
257 the need for standardized screening programs for T. cruzi in Latin American migrants. An early

258 T.cruzi diagnosis allows the individual evaluation and adequacy of the support treatment

259 according to the clinical stage. In addition, it enables the evaluation of the indication of

260 antiparasitic treatment $(55,56)$ in order to reduce the likelihood of progression of the disease

261 as well as being an instrument for interrupting transmission, especially in non-endemic areas

262 through the treatment of women of childbearing age (57-59).

263 In agreement with previous work (19), we found a high prevalence of Strongyloidiasis and an association with $T$. cruzi infection. This further supports maintaining a combined screening strategy of these two pathogens.

The observed high hepatitis A virus prevalence and its association with T.cruzi infection might be due to shared risk factors in terms of low socio economic status and deficient hygienic conditions, although the most frequent means of transmission are essentially different for these two diseases. However, this observation could be conditioned by the fact of having HAV data only of $45.5 \%$ of the patients.

271 Our results show very low chronic hepatitis B virus prevalence $(0.2 \%)$, although up to $7 \%$ of the screened population was immune by past infection. This prevalence of chronic HBV would not justify a systematic screening program in these patients. The most accepted threshold is $2 \%(25-30)$, well above the most ambitious estimates which recommend screening in communities with a prevalence of $0.3 \%$ (24). However, it is possible that the selection of this cohort of patients is not random within Bolivia and that we are facing a healthy migrant bias. Moreover, the fact that patients are screened for HBV a median of 8 years after they arrive, further jeopardizes the probability of diagnosing acute infections. Acute infections acquired prior to departure or in the host country might be wrongly classified due to this long period between arrival and HBV screening. Moreover, no complete serological information was available for almost one third of patients, which constitutes one of the main limitations of the study. There are no updated data on prevalence of HBV or vaccination coverage since its 
283 introduction in 2000 (60). It would be necessary to have up-to-date and robust evidence on

284 the epidemiology of HBV in Bolivia in order to improve the targeted screening of this disease in

285 the absence of other risk factors for HBV. In any case, this scenario of young and healthy

286 patients is common in countries that host migrant population; and therefore it is the basis on

287 which estimates of the necessary screening can be made, in the absence of reliable

288 epidemiological data from the countries of origin.

Due to the negative gradient of the prevalence of hepatitis $\mathbf{C}$ virus in Spain with respect to

Bolivia, the systematic screening of this disease in the absence of other risk factors would not

be granted. However, as some authors recommend, $\mathrm{HCV}$ serology is sometimes performed when requesting other serologies, such as HBV or HIV in young people who are sexually active due to the risk of acquisition in the host country. Our results confirm the relevance of this strategy in both the prevalence of HCV and HIV.

This work supports the relevance of the screening of T.cruzi and strongyloides in people from 
306 The team is supported by the Agencia de Gestió d'Ajuts Universitaris i de Recerca (AGAUR)

307 (2016SGR924) and by the Tropical Disease Cooperative Research Network (RICET)

308 (RD16/0027/0004). ISGlobal is a member of the Centres de Recerca de Catalunya (CERCA)

309 Programme, Government of Catalonia (Spain).

310 Conflict of interest

311 The funders had no role in study design, data collection and analysis, decision to publish, or

312 preparation of the manuscript. None of the authors declares having conflicts of interest. 
1. WHO | Chagas disease (American trypanosomiasis). WHO [Internet]. 2017 [cited 2017 Jun 8]; Available from: http://www.who.int/mediacentre/factsheets/fs340/en/

2. Schmunis GA. Epidemiology of Chagas disease in non-endemic countries: the role of international migration. Mem Inst Oswaldo Cruz [Internet]. 2007 Oct 30 [cited 2019 Jan 18];102 Suppl 1:75-85. Available from: http://www.ncbi.nlm.nih.gov/pubmed/17891282

3. Gascon J, Bern C, Pinazo M-J. Chagas disease in Spain, the United States and other nonendemic countries. Acta Trop [Internet]. 2010 Jul [cited 2017 Jun 8];115(1-2):22-7. Available from: http://linkinghub.elsevier.com/retrieve/pii/S0001706X09001995

4. $\quad$ Pérez de Ayala, Ana; Pérez-Molina, José Antonio; Navarro, Miriam; López-Vélez R. Enfermedad de Chagas en personas procedentes de latinoamérica residentes en España. Minist Sanid y Política Soc [Internet]. 2009 [cited 2018 May 15]; Available from: https://www.msssi.gob.es/profesionales/saludPublica/prevPromocion/promocion/migr acion/docs/enfermedadChagas.pdf

5. Albajar-Viñas $P$, Jannin J. The hidden Chagas disease burden in Europe. Euro Surveill [Internet]. 2011 [cited 2018 Mar 31];16(38). Available from: www.eurosurveillance.org:pii=19975.

6. Howard EJ, Xiong X, Carlier Y, Sosa-Estani S, Buekens P. Frequency of the congenital transmission of Trypanosoma cruzi: a systematic review and meta-analysis. BJOG [Internet]. 2014 Jan [cited 2019 Jan 18];121(1):22-33. Available from: http://doi.wiley.com/10.1111/1471-0528.12396

7. Bern C, Montgomery SP, Katz L, Caglioti S, Stramer SL. Chagas disease and the US blood supply. Curr Opin Infect Dis [Internet]. 2008 Oct [cited 2019 Jan 18];21(5):476-82. Available from: https://insights.ovid.com/crossref?an=00001432-200810000-00006

8. Huprikar S, Bosserman E, Patel G, Moore A, Pinney S, Anyanwu A, et al. Donor-Derived Trypanosoma cruzi Infection in Solid Organ Recipients in the United States, 2001-2011. Am J Transplant [Internet]. 2013 Sep [cited 2019 Jan 18];13(9):2418-25. Available from: http://www.ncbi.nlm.nih.gov/pubmed/23837488

9. Pottie MCISc K, Greenaway C, Feightner J, Welch V, Swinkels MHSc H, Rashid M, et al. Evidence-based clinical guidelines for immigrants and refugees for summary of recommendations and clinical considerations. CMAJ [Internet]. 2011 [cited $2018 \mathrm{Dec}$ 13];(12):183. Available from: www.cmaj.ca/lookup/suppl/doi:10.1503/cmaj.090313//DC1

10. Van Der Werf J, Derrough T, Duffell E, Pharris A, Suk J, De H, et al. Public health guidance on screening and vaccination for infectious diseases in newly arrived migrants within the EU/EEA Public health guidance on screening and vaccination for infectious diseases in newly arrived migrants within the EU/EEA [Internet]. 2018 [cited 2018 Dec 13]. Available from: https://www.ecdc.europa.eu/en/news-events/ecdc-issuesmigrant-screening-and-vaccination-guidance

11. Cochrane A, Evlampidou I, Irish C, Ingle SM, Hickman M. Hepatitis B infection prevalence by country of birth in migrant populations in a large UK city. J Clin Virol [Internet]. $2015 \mathrm{Jul}$ [cited $2017 \mathrm{Dec} 20$ ];68:79-82. Available from: http://www.ncbi.nlm.nih.gov/pubmed/26071342 
12. Requena-Méndez A, Aldasoro E, de Lazzari E, Sicuri E, Brown M, Moore DAJ, et al. Prevalence of Chagas disease in Latin-American migrants living in Europe: a systematic review and meta-analysis. Rodrigues MM, editor. PLoS Negl Trop Dis [Internet]. 2015 Feb 13 [cited 2017 Jun 8];9(2):e0003540. Available from: http://dx.plos.org/10.1371/journal.pntd.0003540

13. Requena-Méndez A, Bussion S, Aldasoro E, Jackson $Y$, Angheben A, Moore $D$, et al. Costeffectiveness of Chagas disease screening in Latin American migrants at primary healthcare centres in Europe: a Markov model analysis. Lancet Glob Heal [Internet]. 2017 Apr [cited 2017 Jun 8];5(4):e439-47. Available from: http://www.ncbi.nlm.nih.gov/pubmed/28256340

14. Sicuri E, Muñoz J, Pinazo MJ, Posada E, Sanchez J, Alonso PL, et al. Economic evaluation of Chagas disease screening of pregnant Latin American women and of their infants in a non endemic area. Acta Trop [Internet]. 2011 May [cited 2019 Jan 18];118(2):110-7. Available from: http://www.ncbi.nlm.nih.gov/pubmed/21396345

15. Bisoffi Z, Buonfrate D, Montresor A, Requena-Méndez A, Muñoz J, Krolewiecki AJ, et al. Strongyloides stercoralis: a plea for action. Lammie PJ, editor. PLoS Negl Trop Dis [Internet]. 2013 May 9 [cited 2018 Apr 30];7(5):e2214. Available from: http://dx.plos.org/10.1371/journal.pntd.0002214

16. Schär F, Trostdorf U, Giardina F, Khieu V, Muth S, Marti H, et al. Strongyloides stercoralis: Global Distribution and Risk Factors. PLoS NegI Trop Dis [Internet]. 2013 [cited 2018 Apr 30];7(7):e2288. Available from: http://www.ncbi.nlm.nih.gov/pubmed/23875033

17. BUONFRATE D, MENA MA, ANGHEBEN A, REQUENA-MENDEZ A, MUÑOZ J, GOBBI F, et al. Prevalence of strongyloidiasis in Latin America: a systematic review of the literature. Epidemiol Infect [Internet]. 2015 Feb 3 [cited 2018 Apr 30];143(03):452-60. Available from: http://www.ncbi.nlm.nih.gov/pubmed/24990510

18. Buonfrate D, Requena-Mendez A, Angheben A, Muñoz J, Gobbi F, Van Den Ende J, et al. Severe strongyloidiasis: a systematic review of case reports. BMC Infect Dis [Internet]. 2013 Feb 8 [cited 2019 Jan 18];13(1):78. Available from: http://bmcinfectdis.biomedcentral.com/articles/10.1186/1471-2334-13-78

19. Puerta-Alcalde P, Gomez-Junyent J, Requena-Mendez A, Pinazo MJ, Álvarez-Martínez $\mathrm{MJ}$, Rodríguez $\mathrm{N}$, et al. High prevalence of $\mathrm{S}$. Stercoralis infection among patients with Chagas disease: A retrospective case-control study. Arndt MB, editor. PLoS Negl Trop Dis [Internet]. 2018 Jan 31 [cited 2018 Apr 30];12(1):e0006199. Available from: http://www.ncbi.nlm.nih.gov/pubmed/29385128

20. WHO. Global Hepatitis Report [Internet]. 2017 [cited 2017 Nov 29]. Available from: http://apps.who.int/iris/bitstream/10665/255016/1/9789241565455-eng.pdf?ua=1

21. Wilson J, Jungner G, Organization WH. The principles and practice of screening for disease. 1966 [cited 2018 May 1]; Available from: http://apps.who.int/iris/bitstream/10665/208882/1/WHO_PA_66.7_eng.pdf

22. Weinbaum CM, Williams I, Mast EE, Wang SA, Finelli L, Wasley A, et al. Recommendations for identification and public health management of persons with chronic hepatitis B virus infection. MMWR Recomm reports Morb Mortal Wkly report Recomm reports [Internet]. 2008 Sep 19 [cited 2018 Apr 30];57(RR-8):1-20. Available from: http://www.ncbi.nlm.nih.gov/pubmed/18802412 
23. Hahné SJ, Veldhuijzen IK, Wiessing L, Lim T-A, Salminen M, Van De Laar M. Infection with hepatitis $B$ and $C$ virus in Europe: a systematic review of prevalence and costeffectiveness of screening. BMC Infect Dis [Internet]. 2013 [cited 2017 Nov 27];13:1. Available from: https://www.ncbi.nlm.nih.gov/pmc/articles/PMC3716892/pdf/14712334-13-181.pdf

24. Eckman MH, Kaiser TE, Sherman KE. The cost-effectiveness of screening for chronic hepatitis B infection in the United States. Clin Infect Dis [Internet]. 2011 Jun 1 [cited 2018 Apr 30];52(11):1294-306. Available from: https://academic.oup.com/cid/articlelookup/doi/10.1093/cid/cir199

25. Tavoschi L, Duffel E, Adlhoch C, Aspinall E, Hutchinson S, Goldberg D. Hepatitis B and C testing activities, needs, and priorities in the EU/EEA. [cited 2017 Nov 22]; Available from: https://ecdc.europa.eu/sites/portal/files/documents/HepatitisBC-testing-in-EUMay2017.pdf

26. Hepatitis B and C testing: people at risk of infection | Guidance and guidelines | NICE. [cited 2017 Nov 22]; Available from: https://www.nice.org.uk/guidance/PH43

27. Epidemiological assessment of hepatitis $B$ and $C$ among migrants in the EU/EEA. [cited 2017 Nov 22]; Available from:

https://ecdc.europa.eu/sites/portal/files/media/en/publications/Publications/epidemi ological-assessment-hepatitis-B-and-C-among-migrants-EU-EEA.pdf

28. LeFevre ML, U.S. Preventive Services Task Force. Screening for Hepatitis B Virus Infection in Nonpregnant Adolescents and Adults: U.S. Preventive Services Task Force Recommendation Statement. Ann Intern Med [Internet]. 2014 Jul 1 [cited 2017 Dec 15];161(1):58. Available from: http://www.ncbi.nlm.nih.gov/pubmed/24863637

29. Pottie K, Mayhew AD, Morton RL, Greenaway C, AkI EA, Rahman P, et al. Prevention and assessment of infectious diseases among children and adult migrants arriving to the European Union/European Economic Association: a protocol for a suite of systematic reviews for public health and health systems. BMJ Open [Internet]. $2017 \mathrm{Sep}$ 11 [cited 2017 Sep 15];7(9):e014608. Available from: http://www.ncbi.nlm.nih.gov/pubmed/28893741

30. Abara WE, Qaseem A, Schillie S, McMahon BJ, Harris AM, High Value Care Task Force of the American College of Physicians and the Centers for Disease Control and Prevention. Hepatitis B Vaccination, Screening, and Linkage to Care: Best Practice Advice From the American College of Physicians and the Centers for Disease Control and Prevention. Ann Intern Med [Internet]. 2017 Dec 5 [cited 2017 Dec 14];167(11):794. Available from: http://www.ncbi.nlm.nih.gov/pubmed/29159414

31. WHO | Monitoring and evaluation for viral hepatitis B and C: recommended indicators and framework. WHO [Internet]. 2016 [cited 2018 Apr 30]; Available from: http://www.who.int/hepatitis/publications/hep-b-c-monitoring-evaluation/en/

32. Zampino R, Boemio A, Sagnelli C, Alessio L, Adinolfi LE, Sagnelli E, et al. Hepatitis B virus burden in developing countries. World J Gastroenterol [Internet]. 2015 Nov 14 [cited 2017 Dec 20];21(42):11941. Available from: http://www.ncbi.nlm.nih.gov/pubmed/26576083

33. Kowdley K V., Wang CC, Welch S, Roberts H, Brosgart CL. Prevalence of chronic hepatitis $\mathrm{B}$ among foreign-born persons living in the United States by country of origin. Hepatology. 2012;56(2):422-33. 
34. Schweitzer A, Horn J, Mikolajczyk RT, Krause G, Ott JJ. Estimations of worldwide prevalence of chronic hepatitis $B$ virus infection: a systematic review of data published between 1965 and 2013. Artic 1546 www.thelancet.com Funding World Heal Organ [Internet]. [cited 2017 Nov 29]; Available from: https://www-clinicalkey-com.mhdoct.a17.csinet.es/service/content/pdf/watermarked/1-s2.0S014067361561412X.pdf?locale=es_ES

35. Gower E, Estes C, Blach S, Razavi-Shearer K, Razavi H. Global epidemiology and genotype distribution of the hepatitis C virus infection. [cited 2017 Nov 27]; Available from: https://www-clinicalkey-com.mhdoct.a17.csinet.es/service/content/pdf/watermarked/1-s2.0S0168827814005261.pdf?locale=es_ES

36. Epidemiological assessment of hepatitis $B$ and $C$ among migrants in the EU/EEA.

37. Monge-Maillo B, López-Vélez R, Ferrere-González F, Norman FF, Martínez-Pérez Á, Pérez-Molina JA. Screening of Imported Infectious Diseases Among Asymptomatic SubSaharan African and Latin American Immigrants: A Public Health Challenge. Am J Trop Med Hyg [Internet]. 2015 Apr 1 [cited 2017 Dec 20];92(4):848-56. Available from: http://www.ncbi.nlm.nih.gov/pubmed/25646257

38. Pahissa A, Salvador F, Sánchez-Montalvá A, Bocanegra C, Molina I, Sulleiro E. Screening for Imported Diseases in an Immigrant Population: Experience from a Teaching Hospital in Barcelona, Spain. Am J Trop Med Hyg [Internet]. 2014 Dec 3 [cited 2018 Jan 8];91(6):1277-81. Available from: http://www.ncbi.nlm.nih.gov/pubmed/25331805

39. Valerio L, Barro S, Pérez B, Roca C, Fernández J, Solsona L, et al. [Seroprevalence of chronic viral hepatitis markers in 791 recent immigrants in Catalonia, Spain. Screening and vaccination against hepatitis B recommendations]. Rev Clin Esp [Internet]. 2008 Oct [cited 2018 Apr 26];208(9):426-31. Available from: http://www.ncbi.nlm.nih.gov/pubmed/19000469

40. Cochrane A, Evlampidou I, Irish C, Ingle SM, Hickman M. Hepatitis B infection prevalence by country of birth in migrant populations in a large UK city. J Clin Virol. 2015 Jul;68:79-82.

41. C2009 Abbott Laboratories. ABBOTT PRISM Chagas assay Ref 7K35-68. (43).

42. (C) Vircell SL. Granada Spain. T1020: Prueba inmunoenzimática indirecta para determinar anticuerpos IgG+lgM frente a Trypanosoma cruzi en suero humano. 2012;1-4.

43. World Health Organisation. Control of Chagas Disease: second report of the WHO Expert Committee. Brasilia, Brazil; 2002.

44. (C) SCIMEDX CORPORATION. Strongyloides serology microwell ELISA. Dover;USA.

45. (C) 2014 Siemens Healthcare Diagnostics. Tarrytown NU. ADVIA Centaur ${ }^{\circledR}$ HBsAgII REF 10492138. 2014;1-18.

46. (C) 2014 Siemens Healthcare Diagnostics. Tarrytown NU. ADVIA Centaur ${ }^{\circledR}$ HBc Total REF 07566733. 2014;1-18.

47. (C) 2009 Siemens Healthcare Diagnostics Inc. Tarrytown NU. ADVIA Centaur ${ }^{\circledR}$ Anti-HBs2 (aHBs2). Vol. 2. 2012. p. 1-18.

48. (C) 2014 Siemens Healthcare Diagnostics. Tarrytown NU. ADVIA Centaur aHAVT ${ }^{\circledR}$ REF 
05498862. 2014;1-18.

49. (C) 2014 Siemens Healthcare Diagnostics. Tarrytown NU. ADVIA Centaur ${ }^{\circledR}$ HCV REF 03438099. 2014;1-22.

50. (C) 2014 Siemens Healthcare Diagnostics. Tarrytown NU. ADVIA Centaur ${ }^{\circledR}$ HIV 1/O/2 Enhanced REF 01463908. 2014;1-22.

51. StataCorp. Stata Statistical Software: Release 15. Coll. Coll Station TX. 2017;(StataCorp LLC).

52. Cortes G. Partir para quedarse. Institut français d'études andines; 2004.

53. Requena-Méndez A, Aldasoro E, de Lazzari E, Sicuri E, Brown M, Moore DAJ, et al. Prevalence of Chagas Disease in Latin-American Migrants Living in Europe: A Systematic Review and Meta-analysis. Rodrigues MM, editor. PLoS Negl Trop Dis [Internet]. 2015 Feb 13 [cited 2018 Feb 14];9(2):e0003540. Available from: http://www.ncbi.nlm.nih.gov/pubmed/25680190

54. Dias JCP, Silveira AC, Schofield CJ. The impact of Chagas disease control in Latin America: a review. Mem Inst Oswaldo Cruz [Internet]. 2002 Jul [cited 2019 Apr 11];97(5):603-12. Available from: http://www.ncbi.nlm.nih.gov/pubmed/12219120

55. Alonso-Vega C, Alves F, Strub-Wourgaft N, Torrico F, Gascon J, Ortiz L, et al. Treatment of adult chronic indeterminate Chagas disease with benznidazole and three E1224 dosing regimens: a proof-of-concept, randomised, placebo-controlled trial. Lancet Infect Dis [Internet]. 2018 [cited 2018 Dec 5];18:419-49. Available from: http://dx.doi.org/10.1016/

56. Viotti R, Vigliano C, Lococo B, Bertocchi G, Petti M, Alvarez MG, et al. Long-term cardiac outcomes of treating chronic Chagas disease with benznidazole versus no treatment: a nonrandomized trial. Ann Intern Med [Internet]. 2006 May 16 [cited 2018 May 20];144(10):724-34. Available from: http://www.ncbi.nlm.nih.gov/pubmed/16702588

57. Murcia L, Simón M, Carrilero B, Roig M, Segovia M. Treatment of Infected Women of Childbearing Age Prevents Congenital Trypanosoma cruzi Infection by Eliminating the Parasitemia Detected by PCR. J Infect Dis J Infect Dis ${ }^{\circledR}$ [Internet]. 2017 [cited 2018 Dec 7];215:1452-60. Available from: https://academic.oup.com/jid/articleabstract/215/9/1452/2993887

58. Moscatelli G, Moroni S, García-Bournissen F, Ballering G, Bisio M, Freilij H, et al. Prevention of congenital Chagas through treatment of girls and women of childbearing age. Mem Inst Oswaldo Cruz, Rio Janeiro [Internet]. 2015 [cited 2018 Dec 7];110(4):507-9. Available from: https://www.ncbi.nlm.nih.gov/pmc/articles/PMC4501414/pdf/0074-0276-mioc-110-40507.pdf

59. Fabbro DL, Danesi E, Olivera V, Codebó MO, Denner S, Heredia C, et al. Trypanocide Treatment of Women Infected with Trypanosoma cruzi and Its Effect on Preventing Congenital Chagas. Büscher P, editor. PLoS Negl Trop Dis [Internet]. 2014 Nov 20 [cited 2018 Dec 7];8(11):e3312. Available from: www.plosntds.org

60. Cruz S, Potosí B, Paz L. Bolivia Country Profile Health in the Americas 2007 [Internet]. 2007 [cited 2018 Sep 10]. Available from: https://www.paho.org/pahousaid/index.php?option=com_docman\&view=download\&alias=10285-bolivia-countryprofile-health-in-the-americas-2007\&category_slug=hss-salud-en-las- 
bioRxiv preprint doi: https://doi org/10.1101/775890; this version posted September 19,2019 . The copyright holder for this preprint (which was not certified by peer review) is the author/funder, who has granted bioRxiv a license to display the preprint in perpetuity. It is made available under aCC-BY 4.0 International license.

americas\&ltemid=3505\&lang=es

536

537 Supporting Information Legends

538 S1 Checklist: STROBE Checklist

539 